This item was submitted to Loughborough's Research Repository by the author.

Items in Figshare are protected by copyright, with all rights reserved, unless otherwise indicated.

\title{
Organisation development
}

PLEASE CITE THE PUBLISHED VERSION

PUBLISHER

(C) WEDC, Loughborough University

VERSION

VoR (Version of Record)

\section{PUBLISHER STATEMENT}

This work is made available according to the conditions of the Creative Commons Attribution-NonCommercialNoDerivatives 4.0 International (CC BY-NC-ND 4.0) licence. Full details of this licence are available at: https://creativecommons.org/licenses/by-nc-nd/4.0/

\section{LICENCE}

CC BY-NC-ND 4.0

\section{REPOSITORY RECORD}

Franklin, R.. 2019. “Organisation Development”. figshare. https://hdl.handle.net/2134/30705. 
7th 42305 Conference: Water people and waste in developing countries: 1981

ORGANISATION DEVELOPMENT

R. FRANKLIN Consultant, UK.

\section{Introduction}

In order to complete a task which is beyond the capabilities or resources of a single individual it is necessary to develop some kind of organisation. The supply of water to, or collection and dispogal of waste from communities are the sort of tasks requiring organisations. When these tasks are defined in more detail, for example the quantity and quality of water to be supplied to a community within defined boundaries, they are termed the definitive objectives of the organisation. Water supply and waste disposal organisations have a second objective which is to survive and this is sometimes not adequately considered. If an organisation is set up to design and/or to construct specific works only, then the survival objective will not be relevant. In order to achieve its objectives the organisation carries out activities with resources which it either acquires or already possesses. The resources may be divided into three categories: physical, time, human. The physical rescurces required will differ considerably depending on the organisation objective. The possible utilisation of time will. also vary. The human resource is consistently the raw material of organisation structures and is probably the most variable and difficult resource to use. In addition to people within the organisation there are people outside who will be affected by and who may influence the organisation's activities.

\section{Organisation structures}

Various organisational. structures can be illustrated diagrammatically, the simplest form being añ authoritarian structure whereby one individual makes decisions on the utilisation of resources, and possibly also on objectives. Diagram 1 illustrates a simplified form of authoritarian gtructure. The manager nay be answexable to shareholders or similar interested parties but executive control and power is wielded by the manager.

When the scale of operations grows so that effective control by an individual becomes impossible the organisational structure must be changed so that the organisation and the manager can survive. A manager should have foreseen that a change would be necessary; and should have considered the available options. In this way any changes will be planned and therefore likely to be successful and suitable to the circumstances. Haphazard changes or improvisations are less effective than planned changes. One option available may be to extend the authoritarian system by appointing a manager to develop his own authoritarian network in individual functions or services. This would result in a number. of almost separate units reporting to the general manager who would no longer exexcise the same detailed control of the functions as previously. This is shown in diagram 2 . Further growth involves the preparation of a great deal of vexy varied information for use by the managers. This can often be done most effectively by special supporting staff, thus leading to a third possible structure as shown in diagran 3. Another a.lternative would be to develop very specialized seperate groups as shown in diagram 4 , which could be used by contractors or consultants working on water supply or waste disposal projects. A development of this structure would use a project control section. This section would be responsible for projects, which may involve specialists from several other sections. On completion of the projects the specialists would either move to other project teans or return to specialized work within their own section.

\section{People in organisations}

Organisation structures can only exist and operate if there are people able and willing to fill the different roles within the organisation. A role not shown on any of the previous simple diagrams is that of policy making. The policy makers or governing body are not concerned with the day to day operations of the organisation. The General Manager is responsible for ensuring that daily operations are in accordance with the policy adopted by the governing body. There may be cases where people undertake two roles, for example the General Manager may be a member of the governing body and at the same time has executive responsibilities. Other examples of dual roles may occur; the manager of a water testing laboratory may also advise a waterworks manager on water treatment. Care is needed to ensure that there is no misunderstanding about the role in which 
actions are taken. Every individual in an organisation has their own view of what their role is, or should be, within the organisation. These views will be affected by an individual's abilities, personal objectives and attitudes to colleagues. Consequently the actual organisational development may not be as neat and simple as an organisation diagram implies. All managers have certain powers associated with their position; these may be enhanced or diminished because of personal character, expert knowledge, control of a resource or control of information; factors which may be possessed by non-managers, thus giving some power to influence actions which would not normally be associated with their role. In addition to people in the governing body and managerial positions there will be those directly concerned with production and others concerned with supplying services to the production and managerial groups. In water supply and waste disposal organisations this means quite a wide range of abilities are required from professionally qualified to unskilled manual workers.

\section{People outside the organisation}

Groups outside an organisation who may exert some influence on development and activities include politicians, customers, suppliers of services or resources, government departments and Trade Unions. In the case of water supply and waste disposal organisations which are generally government sponsored, the politicians can probably influence the resources avallable. Customers will often exert pressure on political representatives or may affect the acquisition of resources by withholding payments. Suppliers may affect procedures because of the quantity or quality of their product or because of their commercial practices. Government departments' activities may increase the need for water supply or waste disposal or make the acquisition of foreign resources difficult. Trade Unions can affect procedures, staffing levels and remuneration levels. As the individual members of these external groups develop and change, the interrelationship between the groupsalso will change and may result in organisational changes.

\section{Constraints on organisational development}

Water supply or waste disposal organisations cannot develop if there is a reduced demand for their services due to large scale emigration or other causes. Alternatively development is difficult when there is a shortage of people with adequate training and education to 1111 all the roles in the organisation. This sort of problem may be solved by redistribution of tasks or in the setting up of training racilities. The latter course may generate new problems in obtaining resources and people for training programmes. other constraints may be due to geographical and climatic factors, for example there are physical limitations on the development of island or desert communities. Communication and provision of resources may be restricted by snows, floods, forests or mountains. Wherever such constraints occur special provisions and possibly training will be necessary for the continued effective operation of an organisation. Communications are an important aspect of any organisation; the successful completion of any activity is dependant on communications. Potential communication difficulties may arise from differences in education, use of technical words, use of slang words, dialect, language or lack of understanding of the means of communication. Communication of information on the availability, quality and location of resources is as important as communication on activities. Communication deficiencies could therefore affect the obtaining of resources.

Finance is necessary for obtaining resources such as power, equipment or people. Therefore any restriction on the availability of finance could prevent or defer obtaining the necessary resources for achievement of objectives. Development of an organtsation requires finance in order to acquire the additional physical and human resources essential to growth.

Co-ordination with other authorities concerned with water use or waste generation may impose a constraint on organisation development, particularly when there is legislation defining government departments to be consulted.

\section{Example of a rural water supply authority}

The formation of a rural water supply authority or a waste disposal organisation can mean developing a completely new organisation where none previously existed. The following details derived from a rural water supply authority development iIIustrate the application of some of the points discussed previously. The full development planned to be completed in twenty five years would consist of about 3200 new works of various sizes. About ?\% of the new works would involve an extension of $50 \%$ or more to existing municipal waterworks. The new authority should design and construct the new works as well as operate them after construction. The legislation setting up the authority required that it be an autonomous body and also required co-operation and co-ordination with various concerned government departments at two levels. The provision of water supplies to a large number of rural communities being the purpose of the new authority, it was considered most suitable that the management of these numerous 
86

waterworks would be the executive backbone of the organisation. The large number of works meant several management levels would be required and this afforded an opportuntty of ensuring the required co-operation with government departments. An expansion of the structure shown in diagram 3 was evolved for the ultimate 25 year development programme. The resulting diagram of the executive chain and corresponding government levels is shown in diagram 5 .

A maximum span of management of six is obtained with this arrangement. In addition to the executive chain there would be a need for staff to deal with operating data, performance monitoring, quality testing as well as accounts budgetary control, wages and administration necessary at each level to Area Manager. Planning of new works and monitoring the progress of a 25 year Master Plan was included in the staff work at the Chief Executive's office and at each Regional Director's office. The staff work at individual works would usually be handled by one clerk. In addition to staff various services would be required. A Director of Technical Services would control workshops, transport, supply and stores, and building maintenance. Due to the large programme of works to be undertaken a project construction department would be necessary and a seperate training department also would be required. These were also regarded as services to the executive and staff. The total staff required for the ultimate organisation would be approximately 39700 and the population to be supplied would be just under eight and three quarter millions. The government had decided on the construction period of 25 years but any change in the construction rate would affect the organisation development. The construction programme was split into five five year plans. The organisation development was split into three phases, first the Feasibility Phase, second construction phase build-up, and thirdly construction phase rundown.

During the Feasibility Phase conducted by the embryo staff at the Chief Executive and Regional Director's offices the work consisted of planning projects and training. The assistance of expatriate consulting engineers was obtained in order to prepare design standard manuals which would facilitate future design work. Mobile laboratories were also used to take samples and examine the quality of sources. Some officers transferred from government departments where they had obtained relevant experience but many technical officials had little previous experience. Consequently the initiation of good training facilities $w 11$ be very important; in some categories it has been possible to arrange with existing outside institutions to provide training. One problem, which is common to many countries is that on completion of training some people will leave the organisation for better paid work elsewhere. The training facilities need to allow for this sort of wastage.

During the construction build-up phase the organisation's own workforce would not build up to the level necessary to complete the ful1 construction programe. The excess load would be undertaken by contractors. During the first construction phase the experience in construction will help to determine whether more use should be made of contractors for future construction. When the construction rate is reduced in the second construction phase there will probably be a need to switch some staff from design and construction to operation work. The development of workshops, stores, laboratories and vehicle fleets will be finalised in the second phase.

The periods of change when construction rate is increasing, when comnisstonjing work is at its peak and when construction rate is declining are periods when there is a tendency to incur unnecessary labour costs. Care will be needed in forecasting the staff needs during these periods of change. Good judgement will be required in deceiding when it is necessary to create a District office or an Area Office.

The professional, scientific and managerial staff would be recruited from urban areas but the majority of manual workers, whether skilled or not, are to be recruited from the rural communities. In these communities almost half of the population over the age of twenty are illiterate and this may impose constraints on the operating procedures and require special training facilities. In some areas the local education authorities are able to assist in helping to teach employees to read and write. The provision of incentives may be necessary to encourage employees to learn to read and write.

Having decided the numbers and categories of staff needed an investigation was made to ascertain whether the numbers were likely to be available to the organisation. The professional categories such as engineers, chemists, geologists and bacteriologists appeared to be being trained in adequate numbers. There appeared to be a potential shortage of accountants during the early years of the organisation but the educational institutions were preparing to increase the numbers of accountancy students. Technical sub-professional categories such as surveyors, laboratory technicians and draughtsmen are not likely to be produced in adequate numbers for some years and shortage of these categories could cause acute problems.

No difficulty is envisaged in recruiting suitable people for administrative posts. Training in the organisation's procedures would be necessary. Technical and administrative supervisors could also be a problem area; it may be possible to attract 
competent supervisors from other organisations or, more likely, the training of apparently suitable people will be undertaken by the organisation. There may be difficulty in assessing craftsmen until examples of their work have been seen because of a lack of standard for most craftsmen in the country. There will be no problems in recruiting semiskilled workers who would undergo training in the organisation. There may be difficulty in providing the training. There will be a shortage of managers, both operational and constructional, but management training facilities exist.
The early years of the organisation have followed the predicted development reasonably well. Modifications and adjustments will occur at every stage but having an overall view of what is eventually required will enable the effect of changes to be assessed more easily. The actions and interactions of people in the organisation help to determine the way in which the organisation develops. Organisations sometimes seem to have a life of their own, but like growing children, their development is influenced by the people associated with them.

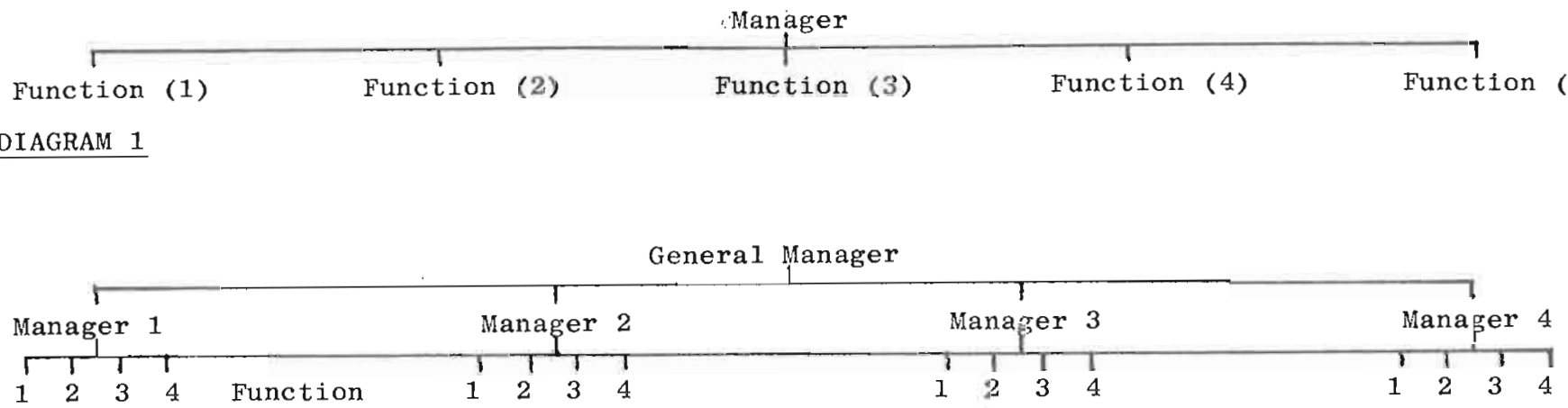

DIAGRAM 2

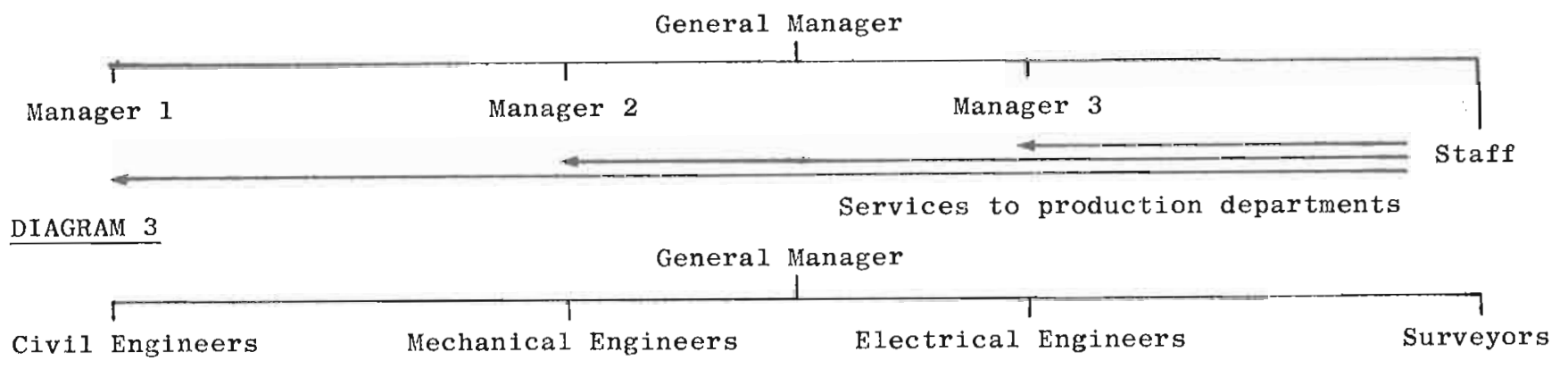

\section{DIAGRAM 4}

Government level

Minister

No of Govt Offices

1

Province

16

Provincial

96

Sub-Division

Sub-Area

277
Water Authority

Council and

No of Water Offices

Chief Executive<smiles>C=C</smiles>

Regional Director

3

District Manager

16

Area Manager

96

1
Works Manager 